\title{
Arterial Hypertension and other risk factors associated with cardiovascular diseases among adults ${ }^{1}$
}

\author{
Cremilde Aparecida Trindade Radovanovic ${ }^{2}$ \\ Lucimary Afonso dos Santos ${ }^{3}$ \\ Maria Dalva de Barros Carvalho ${ }^{4}$ \\ Sonia Silva Marcon ${ }^{5}$
}

\begin{abstract}
Objective: to identify the prevalence of arterial hypertension and its association with cardiovascular risk factors among adults. Method: cross-sectional, population-based, descriptive study conducted with 408 adult individuals. Data were collected through a questionnaire and measurements of weight, height and waist circumference. Person's Chi-square and multiple logistic regression were used in the data analysis. Results: $23.03 \%$ of the individuals reported hypertension with a higher prevalence among women. Odds Ratio indicated that smoking, body mass index, waist circumference, diabetes mellitus and dyslipidemia were positively associated with arterial hypertension. Conclusion: high self-reported hypertension and its association with other cardiovascular risk factors such as diabetes, obesity and dyslipidemia show the need for specific nursing interventions and the implementation of protocols focused on minimizing complications arising from hypertension, as well as to prevent the emergence of other cardiovascular diseases.
\end{abstract}

Descriptors: Hypertension; Cardiovascular Diseases; Risk Factors; Adults.

\footnotetext{
${ }^{1}$ Paper extracted from doctoral dissertation "Factors and cardiovascular risk behaviors in adults resident in Paiçandu - Paraná - effects of an intervention in health", presented to Universidade Estadual de Maringá, Maringá, PR, Brazil. Supported by Fundação Araucária, process \# 19510/2010, Brazil.

2 PhD, Adjunct Profesor, Universidade Estadual de Maringá, Maringá, PR, Brazil. ${ }^{3} \mathrm{PhD}$, Adjunct Professor, Universidade Estadual do Paraná, Paranavaí, PR, Brazil.

${ }^{4} \mathrm{PhD}$, Associate Professor, Universidade Estadual de Maringá, Maringá, PR, Brazil.

${ }^{5} \mathrm{PhD}$, Full Professor, Universidade Estadual de Maringá, Maringá, PR, Brazil.
}

Corresponding Author:

Cremilde Aparecida Trindade Radovanovic

Rua Jaspe, 256

Jardim Brasil

CEP: 87083-276, Maringá, PR, Brasil

E-mail: kikanovic2010@hotmail.com
Copyright (c) 2014 Revista Latino-Americana de Enfermagem This is an Open Access article distributed under the terms of the Creative Commons Attribution Non-Commercial License (CC BY-NC).

This license lets others distribute, remix, tweak, and build upon your work non-commercially, and although their new works must also acknowledge you and be non-commercial, they don't have to license their derivative works on the same terms. 


\section{Introduction}

Cardiovascular diseases (CVD) are currently the leading cause of deaths worldwide. These diseases accounted for more than 17 million deaths in 2008, three million of which occurred before the age of 60. Most could have been avoided. The World Health Organization estimates that around 23.6 million people will die of cardiovascular diseases in 2030(1).

Among the CVD, systemic arterial hypertension (SAH) is an important risk factor for cardiac and cerebrovascular complications ${ }^{(1)}$. It is considered a public health problem around the world. In 2000, the prevalence of $\mathrm{SAH}$ in the world population was $25 \%$ and the estimate for 2025 is $29 \%{ }^{(2)}$. The prevalence of hypertension verified in studies conducted in Brazil ranged from $22.3 \%$ to $43.9 \%$, with an average of $32.5 \%{ }^{(3-4)}$.

In virtually all nations, the prevention and control of SAH has important implications and the use of new strategies and approaches to identify with greater accuracy the individuals at risk benefit both the individuals with hypertension and society(5). Because $\mathrm{SAH}$ is a chronic disease, however, it requires monitoring and treatment for life, involving both pharmacological and non-pharmacological measures ${ }^{(6)}$.

Considering the high levels of morbidity and mortality caused by cardiovascular diseases in Brazil and in the world, and the prevalence of arterial hypertension coupled with a scarcity of studies addressing this topic in small towns in the Southern region of Brazil, this study's aim was to identify the prevalence of arterial hypertension and its association with cardiovascular risk factors among adult individuals in Paiçandu, PS, Brazil.

\section{Method}

This cross-sectional, population-based, descriptive study was conducted with adult individuals living in Paiçandu, PR, Brazil. This town has a total area of $170.64 \mathrm{~km}^{2}$ and an estimated population of 35,941 inhabitants, 19,776 of which are adults aged between 20 and 59 years old.

To define the sample size, a prevalence of $50 \%$ of cardiovascular risk factors was considered together with an estimated error of $5 \%$ and reliability and precision of the sample is set at $95 \%$, adding $10 \%$ for potential losses, resulting in 415 individuals. A total of 408 individuals aged between 20 and 59 years old, both sexes, participated in this study, while only valid data were considered for some variables.
The individuals were selected in a systematic random sample in which the streets, blocks and households were randomly drawn. Systematically and with a predefined interval, one individual living in the fourth household on the right side of the street was addressed. When no individuals within the selected age group lived in the house, we moved to the subsequent house in which only one individual was interviewed.

Data were collected from September 2010 to February 2011 through interviews and measurements of weight, height, and waist circumference (WC). The instrument used for the interviews is part of an instrument adopted in a household survey addressing behavioral risk and morbidity of non-communicable diseases $^{(7)}$. This questionnaire was previously tested in a pilot-study with 20 individuals living near the campus of the State University of Maringá, Maringá, PR, Brazil. Small corrections were implemented in the instrument after the pilot-study to improve the level of understanding it provided.

SAH was considered for self-reported cases. Sociodemographic variables were the predictor variables of sex, age, marital status, and economic status, which was used to estimate the purchasing power of individuals and families ${ }^{(8)}$, who were grouped into: A1-A2, B1-B2, C1-C2, and D-E. Variables regarding lifestyle included: smoking, diet and exercise. Smoking referred to individuals smoking regularly regardless of the number of cigarettes; individuals who did not exercise at least three times a week for at least 30 minutes per session were considered to be inactive ${ }^{(9)}$. Diet was considered inadequate when the intake of fruits and/or vegetables and/or legumes was below five times a week ${ }^{(7)}$.

Body mass (in kilograms) was assessed using a portable anthropometric digital scale (150 kilograms maximum capacity and accuracy to 0.1 kilograms). An anthropometric tape was used to measure height (in meters). The individual's weight (in kilograms) divided by the squared height (in meters) was used to compute body mass index (BMI). The values were classified into: normal weight, when BMI >18.50 to $24.99 \mathrm{~kg} / \mathrm{m}^{2}$; overweight, when $B M I \geq 25$ to $29.99 \mathrm{~kg} / \mathrm{m}^{2}$; and obese when BMI $\geq 30 \mathrm{~kg} / \mathrm{m}^{2(9)}$. Abdominal obesity (excessive fat in the abdominal region) was determined when WC was above $102 \mathrm{~cm}$ for men and $88 \mathrm{~cm}$ for women(9), measured at the midpoint between the costal margin and the iliac crest.

The outcome variables were self-reported morbidities, such as diabetes mellitus (DM) and dyslipidemia. To verify the presence of an agglomeration of risk factors, scores ranged from none $(0)$ to five 
(5) or more risk factors. Zero was scored when there was no exposure to any factors, 1 - when there was exposure to one factor, 2 - exposure to two risk factors, 3 - exposure to three factors, 4 - exposure to four factors, and 5 - exposure to five or more risk factors. Data were recorded in a database in Microsoft Office Excel 2007; double entry was used to check later for inconsistencies, and data analysis was performed using the R Environment for Statistical computing. The statistical analysis used to identify the Odds Ratio (OR) was univariate analysis considering hypertension in each of the variables (sex, age, economic status, marital status, exercise, diet, smoking, cholesterol, BMI, WC, and DM). Multiple logistic regression was performed using $\mathrm{SAH}$ as the outcome and all the variables were considered. Afterwards, the model was reassessed and only the variables significant at $5 \%$ were kept. Person's
Chi-square test was used to verify association with the agglomeration of cardiovascular risk factors.

The study was approved by the Institutional Review Board at the State University of Maringá (COPEP-UEM), process No. 173/2010. All the participants signed two copies of free and informed consent forms.

\section{Results}

Most of the 408 adults assessed were women (68.63\%). The prevalence of SAH was $23.03 \%$, higher among women (24.64\%) than among men (19.53\%), though with no significant differences (Table 1). Average age was 39.9 years old \pm 12 years, while $47.71 \%$ of the individuals were aged between 50 and 59 years old. The prevalent economic status was D-E, with $31.82 \%$ of the individuals being hypertensive (Table 1 ).

Table 1 - Prevalence of arterial hypertension according to socio-demographic profile. Paiçandu, PR, Brazil, 2011

\begin{tabular}{|c|c|c|c|c|c|}
\hline \multirow{2}{*}{ Variable* } & \multirow{2}{*}{ Total } & \multicolumn{2}{|c|}{ SAH prevalence } & \multirow{2}{*}{$\begin{array}{l}\text { Raw OR } \\
(\text { Cl95\%) }\end{array}$} & \multirow{2}{*}{ P-value } \\
\hline & & $\mathrm{n}$ & $\%$ & & \\
\hline $\operatorname{Sex}(n=408)$ & & & & & 0.311 \\
\hline Female & 280 & 69 & 24.64 & 1 & \\
\hline Male & 128 & 25 & 19.53 & $0.77(0.45-1.27)$ & \\
\hline Age groups - years $(n=408)$ & & & & & $<0.001$ \\
\hline 20 to 29 & 100 & 09 & 9.00 & 1 & \\
\hline 30 to 39 & 94 & 14 & 14.89 & $1.71(0.71-4.29)$ & \\
\hline 40 to 49 & 105 & 19 & 18.10 & $2.21(0.97-5.37)$ & \\
\hline 50 to 59 & 109 & 52 & 47.71 & $8.76(4.19-20.23)$ & \\
\hline Economic status $(n=399)$ & & & & & 0.014 \\
\hline $\mathrm{A} 1-\mathrm{A} 2 ; \mathrm{B} 1-\mathrm{B} 2$ & 129 & 20 & 15.75 & 1 & \\
\hline $\mathrm{C} 1-\mathrm{C} 2$ & 248 & 67 & 27.02 & $1.99(1.16-3.53)$ & \\
\hline$D-E$ & 22 & 07 & 31.82 & $2.26(0.79-6.01)$ & \\
\hline Marital status ( $n=407)$ & & & & & 0.961 \\
\hline No partner & 132 & 30 & 22.73 & 1 & \\
\hline Partner & 275 & 63 & 22.91 & $0.99(0.61-1.63)$ & \\
\hline
\end{tabular}

*Only valid data were considered

Table 2 shows that the factors most frequently found among hypertensive individuals were DM, obesity and dyslipidemia.

Significant association was found between SAH and smoking $(p<0.001)$, obesity $(p<0.001)$,
WC $(p=0.022)$ DM $(p<0.001)$, and dyslipidemia $(p<0.001)$. The variables exercise and diet presented no significant differences $(p=0.542, p=0.648$, respectively).

Table 2 - Prevalence of arterial hypertension according to cardiovascular risk factors and self-reported morbidities. Paiçandu, PR, Brazil, 2011

\begin{tabular}{|c|c|c|c|c|c|}
\hline \multirow{2}{*}{ Variables* } & \multirow{2}{*}{ Total } & \multicolumn{2}{|c|}{ Prevalence of SAH } & \multirow{2}{*}{$\begin{array}{l}\text { Raw Odds Ratio } \\
\text { (CI 95\%) }\end{array}$} & \multirow{2}{*}{ P-value } \\
\hline & & $\mathbf{n}$ & $\%$ & & \\
\hline Exercise $(n=407)$ & & & & & 0.542 \\
\hline Yes & 90 & 23 & 25.56 & 1 & \\
\hline No & 317 & 71 & 22.40 & $1.18(0.68-2.01)$ & \\
\hline
\end{tabular}


Table 2 - (continuation)

\begin{tabular}{|c|c|c|c|c|c|}
\hline \multirow{2}{*}{ Variables* } & \multirow{2}{*}{ Total } & \multicolumn{2}{|c|}{ Prevalence of SAH } & \multirow{2}{*}{$\begin{array}{l}\text { Raw Odds Ratio } \\
\text { (Cl 95\%) }\end{array}$} & \multirow{2}{*}{ P-value } \\
\hline & & $\mathrm{n}$ & $\%$ & & \\
\hline $\operatorname{Diet}(n=403)$ & & & & & 0.648 \\
\hline Appropriate & 315 & 74 & 23.49 & 1 & \\
\hline Inappropriate & 88 & 19 & 21.59 & $0.88(0.49-1.52)$ & \\
\hline \multicolumn{6}{|l|}{ Smoking $(n=407)$} \\
\hline Non-smoker & 272 & 48 & 17.65 & 1 & $<0.001$ \\
\hline Smoker & 66 & 18 & 27.27 & $1.73(0.91-3.18)$ & \\
\hline Former smoker & 69 & 28 & 40.58 & $3.27(1.84-5.80)$ & \\
\hline BMI $(n=405)$ & & & & & $<0.001$ \\
\hline Normal & 172 & 27 & 15.70 & 1 & \\
\hline Overweight & 144 & 34 & 23.61 & $1.71(0.98-3.02)$ & \\
\hline Obese & 89 & 33 & 37.08 & $3.13(1.74-5.69)$ & \\
\hline Waist circumference $(n=396)$ & & & & & 0.008 \\
\hline Normal & 116 & 18 & 15.52 & 1 & \\
\hline Greater than normal parameters & 280 & 75 & 26.79 & $2.12(1.24-3.76)$ & \\
\hline Diabetes Mellitus ( $n=408)$ & & & & & $<0.001$ \\
\hline No & 376 & 78 & 20.74 & 1 & \\
\hline Yes & 32 & 16 & 50.00 & $3.91(1.86-8.22)$ & \\
\hline Dyslipidemia $(n=408)$ & & & & & $<0.001$ \\
\hline No & 330 & 64 & 19.39 & 1 & \\
\hline Yes & 78 & 30 & 38.46 & $2.6(1.52-4.41)$ & \\
\hline
\end{tabular}

After adjusting the variables, the presence of $\mathrm{SAH}$ was statistically significant for age, smoking, BMI, and DM, as presented in Table 3.

Individuals aged between 50 and 59 years old were 5.35 times more likely to present hypertension compared to those aged from 20 to 29 years old. Smokers are 2.36 times more likely than non-smokers; obese individuals were 2.35 times more likely than those within normal parameters of weight, while individuals with DM are 2.9 times more likely to be hypertensive than individuals without DM.

Table 4 shows that $40.38 \%$ of the hypertensive individuals aged from 50 to 59 years old have five or more cardiovascular risk factors, while $25 \%$ of the hypertensive individuals aged between 20 to 29 years old do not present any cardiovascular risk factors. A total of $33.33 \%$ of the hypertensive individuals aged between 30 and 39 years old presented two risk factors.

Table 3 - Factors associated with arterial hypertension according to multiple regression analysis. Paiçandu, PR, Brazil, 2011

\begin{tabular}{|c|c|c|c|c|}
\hline & Variable & Odds Ratio & $\mathrm{Cl}(95 \%)$ & P-value \\
\hline \multicolumn{5}{|l|}{ Age group - years } \\
\hline 20 to 29 & & 1 & - & - \\
\hline 30 to 39 & & 1.23 & $0.49-3.22$ & 0.655 \\
\hline 40 to 49 & & 1.58 & $0.66-3.98$ & 0.306 \\
\hline 50 to 59 & & 5.35 & $2.41-12.91$ & $<0.001$ \\
\hline \multicolumn{5}{|l|}{ Smoking } \\
\hline Non-smoker & & 1 & - & - \\
\hline Smoker & & 2.36 & $1.13-4.83$ & 0.019 \\
\hline Former smoker & & 2.21 & $1.16-4.18$ & 0.014 \\
\hline \multicolumn{5}{|l|}{ BMI } \\
\hline Normal & & 1 & - & - \\
\hline Overweight & & 1.27 & $0.67-2.43$ & 0.454 \\
\hline Obese & & 2.35 & $1.19-4.64$ & 0.013 \\
\hline \multicolumn{5}{|l|}{ Diabetes Mellitus } \\
\hline No & & 1 & - & - \\
\hline Yes & & 2.89 & $1.27-6.60$ & 0.010 \\
\hline
\end{tabular}


Table 4 - Distribution of hypertensive individuals according to the number of cardiovascular risk factors. Paiçandu, PR, Brazil, 2011

\begin{tabular}{|c|c|c|c|c|c|c|c|c|}
\hline \multirow{3}{*}{$\begin{array}{c}\text { Risk } \\
\text { factors }\end{array}$} & \multicolumn{8}{|c|}{ Age groups (years) } \\
\hline & \multicolumn{2}{|c|}{20 to 29} & \multicolumn{2}{|c|}{30 to 39} & \multicolumn{2}{|c|}{40 to 49} & \multicolumn{2}{|c|}{50 to 59} \\
\hline & $\%$ & CI $95 \%$ & $\%$ & Cl $95 \%$ & $\%$ & $\mathrm{Cl} 95 \%$ & $\%$ & Cl $95 \%$ \\
\hline 0 & 25.00 & $(4.45-64.42)$ & 8.33 & $(0.44-40.25)$ & 10.53 & $(1.84-34.54)$ & 0.00 & $(0.00-8.57)$ \\
\hline 1 & 25.00 & $(4.45-64.42)$ & 16.67 & $(2.94-49.12)$ & 21.05 & $(6.97-46.10)$ & 3.85 & $(0.67-14.33)$ \\
\hline 2 & 12.50 & $(0.66-53.32)$ & 33.33 & $(11.27-64.56)$ & 21.05 & $(6.97-46.10)$ & 17.31 & $(8.69-30.82)$ \\
\hline 3 & 12.50 & $(0.66-53.32)$ & 25.00 & $(6.69-57.16)$ & 10.53 & $(1.84-34.54)$ & 17.31 & $(8.69-0.82)$ \\
\hline 4 & 25.00 & $(4.45-64.42)$ & 8.33 & $(0.44-40.25)$ & 10.53 & $(1.84-34.54)$ & 21.15 & $(11.52-35.09)$ \\
\hline$\geq 5$ & 0.00 & $(0.00-40.23)$ & 8.33 & $(0.44-40.25)$ & 26.32 & $(10.12-51.42)$ & 40.38 & $(27.31-54.87)$ \\
\hline
\end{tabular}

P-value $=0.0385$

\section{Discussion}

The prevalence of SAH identified in this study was similar to that found in a study conducted in Pelotas, in the Southern region of Brazil(10), and less than that observed in other Brazilian studies ${ }^{(4,11)}$ and in studies conducted in the United States(12). It is, however, greater than the prevalence identified in a more comprehensive study conducted in all the Brazilian capitals using selfreported information, which ranged from $14.7 \%$ (in Palmas) to $29.5 \%$ (Rio de Janeiro), with an average of $21.6 \%{ }^{(13)}$. Hypertension was more frequently found among women, which corroborates the findings of other studies conducted with adult(4,13-14) and elderly individuals(4,13-15), though no statistically significant association was observed between sexes, confirming the results reported for Nobres, $\mathrm{MT}^{(4)}$ and Firminópolis, GO, Brazil(11).

This study also shows that the prevalence of hypertension increased with age, as reported by another study $^{(16)}$, while individuals aged between 50 and 59 years old were 5.35 times more likely to present hypertension that individuals aged from 20 to 29 years old.

The variable exercise was not significantly associated with $\mathrm{SAH}$, similar to the results found in one study conducted in Sinop, MT, Brazil, though the authors report that longitudinal studies are more appropriate to assess the effects of exercise on blood pressure(17). Regular exercise is a non-pharmacological measure recommended for the treatment of $\mathrm{SAH}$, not only for its beneficial effect on blood pressure, but also to reduce other cardiovascular risk factors ${ }^{(18)}$.

Likewise, diet was not significantly associated with $\mathrm{SAH}$. Such a result may be associated with the type of methodology employed to assess diet. Only the intake of vegetables, greens and fruits was considered, though the intake of salt and fat is also an important indicator of SAH. Appropriate food intake and the importance of a balanced diet should be stressed and recommended by health professionals with hypertensive patients ${ }^{(14)}$ for its benefit of reducing cardiovascular risks.

In regard to smoking, former smokers presented the highest prevalence of hypertension, which corroborates the findings of other studies(10-11). This study also shows that former smokers and smokers presented significant association with SAH. One study conducted in Japan reports that smoking and $\mathrm{SAH}$ are the two main factors of mortality due to non-communicable diseases among adults ${ }^{(19)}$.

This study found significant association in regard to BMI, similar to the findings of other studies that also show a significant association with $\mathrm{SAH}^{(20-21)}$. The obese individuals in this study were 2.35 times more likely to present hypertension compared to those within a weight range considered to be normal. WC also was an important anthropometric indicator, showing significant association with $\mathrm{SAH}$, corroborating the results reported by a study addressing Chinese individuals ${ }^{(22)}$.

The prevalence of obesity has grown around the world and is considered an important risk factor for $\mathrm{SAH}$. One study conducted in the northern part of China reports that increased BMI is strongly linked to hypertension; however, it only represents the total body weight and is unable to distinguish between excess fat tissue and a large amount of muscle mass(22).

This study shows that individuals with DM are almost three times more likely to develop SAH than individuals without DM. One epidemiological study indicates that DM and hypertension are usually associated conditions ${ }^{(16)}$, confirming data found in this study, that is, that $50 \%$ of the individuals with DM also have hypertension. Selfreported dyslipidemia also was significantly associated with $\mathrm{SAH}$, though this association did not remain after the variable was adjusted. High levels of cholesterol 
associated with hypertension account for more than $50 \%$ of the risk attributed to coronary disease, so that therapeutic measures can reduce morbidity and mortality in diverse conditions of risk $^{(23)}$. We also observed that most individuals with SAH presented more than three cardiovascular risk factors. Additionally, an increase in the number of associated factors was maintained with aging.

This study's limitations are related to three aspects: a) the fact that the participants were selected according to which individuals were present at home at the time of the visit, which resulted in a sample predominantly composed of women; b) SAH was selfreported; and c) the fact that leisure activities were not considered exercise, which led to a high prevalence of sedentariness. In regard to the last two questions, however, it is important to note that self-reported hypertension is considered appropriate to estimating the prevalence of various health conditions in populations and has also been used by the Ministry of Health in the VIGITEL ${ }^{(13)}$ survey. Also, in regard to exercise, we note that an evaluation of a population as being sedentary should generally be viewed with caution, especially when making journeys, domestic and work activities are not taken into account ${ }^{(24)}$.

\section{Conclusion}

The results show that the prevalence of selfreported $\mathrm{SAH}$ was higher among women aged between 50 and 59 years old. In regard to risk factors, the most prevalent were DM, obesity, and dyslipidemias, while these are considered important risk factors for arterial hypertension.

The identification of SAH and its association with other cardiovascular risk factors enabled understanding the health profile of the population under study and aided in the identification of the urgent need for specific nursing interventions, the implementation of protocols focused on minimizing complications arising from arterial hypertension, as well as efforts to prevent the emergence of other cardiovascular diseases. These interventions should be implemented in such a way they enables individuals to discuss issues concerning their chronic conditions and associated risk factors, while at the same time, providing encouragement and support in the promotion of a healthier lifestyle. In this sense, it is highly recommended that nursing professionals and other health professionals, involved with interventions, appreciate the individuals' experiences, knowledge and limitations, and implement individualized actions to provide conditions for effective behavioral changes to occur.

Finally, even though the results obtained here involve only a small town, they show that the number of adult individuals self-reporting hypertension was high, which does not differ from what has been observed in other Brazilian cities of different population sizes, as previously noted. Additionally, the risk factors associated with hypertension identified in this town show that these issues represent a challenge for the health sector in small towns, as well, because these reflect modern lifestyles, such as smoking, inappropriate diet, and sedentariness. These habits result in health problems such as DM, obesity, and dyslipidemia, which, in this study presented significant associations with $\mathrm{SAH}$, an important cause of morbidity and mortality in adults in Brazil and in the world. These findings reinforce the need for further studies comparing lifestyles and behaviors in health with the presence of cardiovascular risk factors in populations living in small and large cities.

\section{References}

1. World Health Organization (WHO). Global Atlas on Cardiovascular Disease Prevention and Control. Mendis S, Puska P, Norrving B editors. Geneva: World Health Organization; 2011.

2. Talaei M, Sadeghi M, Mohammadifard N, Shokouh $P$, Oveisgharan S, Sarrafzadegan N. Incident hypertension and its predictors: the Isfahan Cohort Study. J Hyertension. 2014;32(1):30-8.

3. Cesarino CB, Cipullo JP, Martin JFV, Ciorlia LA, Godoy MRP, Cordeiro JA, et al. Prevalência e fatores sociodemográficos em hipertensos de São José do Rio Preto. Arq Bras Cardiol. 2008;91(1):31-5.

4. Rosário TM, Scala LCNS, França GVA, Pereira MRG, Jardim PCBV. Prevalência, controle e tratamento da hipertensão arterial sistêmica em Nobres, MT. Arq Bras Cardiol. 2009;93(6):672-8.

5. Egan BM. Prediction of incident hypertension. Health implications of data mining in the 'Big Data' era. J Hypertens. 2013;31(11):2123-4.

6. Reiners AAO, Seabra FMF, Azevedo RCS, Sudré MRS, Duarte SJH. Adesão ao tratamento de hipertensos da Atenção Básica. Cienc Cuidado Saúde. 2012; 11(3):581-7.

7. Ministério da Saúde (BR). Instituto Nacional do Câncer. Secretaria de Vigilância em Saúde. Inquérito domiciliar 
sobre comportamento de risco e morbidade referida de doenças e agravos não transmissíveis: Brasil, 15 capitais e Distrito Federal, 2002-2003. Rio de Janeiro: Ministério da Saúde; 2004.

8. Associação Brasileira de Empresas de Pesquisa. Critério de classificação econômica Brasil. [Internet] 2010. [acesso 10 abril 2010]. Disponível em: http:// www.abep.org/novo/Content.aspx?ContentID $=302$

9. World Health Organization (WHO). Diet, nutrition and the prevention of chronic diseases: report of a joint WHO/FAO expert consultation. Geneva: WHO; 2003.

10. Costa JSD, Barcellos FC, Sclowitz ML, Sclowitz IKT, Castanheira M, Olinto MT, et al. Prevalência de hipertensão arterial em adultos e fatores associados: um estudo de base populacional urbana em Pelotas, Rio Grande do Sul, Brasil. Arq Bras Cardiol. 2007; 88(1):59-65.

11. Nascente FMN, Jardim PCBV, Peixoto $M$ do RG, Monego ET, Barroso WKS, Moreira HG, et al. Hipertensão arterial e sua associação com índices antropométricos em adultos de uma cidade de pequeno porte do interior do Brasil. Rev Assoc Med Bras. 2009; 55(6):716-22.

12. Yoon SS, Burt V, Louis T, Carroll MD. Hypertension among adults in the United States, 2009-2010. National Center for Health Statistics - NCHS Data Brief. 2012;107.

13. Muraro $A P$, Santos DF dos, Rodrigues PRM, Braga

JU. Fatores associados à Hipertensão Arterial Sistêmica autorreferida segundo VIGITEL nas 26 capitais brasileiras e no Distrito Federal em 2008. Ciênc Saúde Coletiva. 2013;18(5):1387-98.

14. Borges HP, Cruz N do C, Moura EC. Associação entre hipertensão arterial e excesso de peso em adultos, Belém, Pará, 2005. Arq Bras Cardiol. 2008; 91(2):110-8.

15. Tavares DM dos S, Paiva MM de, Dias FA, Diniz MA, Martins NPF. Socio-demographic characteristics and quality of life of elderly patients with systemic arterial hypertension who live in rural areas: the importance of nurses' role. Rev. Latino-Am. Enfermagem. 2013;21(2):515-22.

16. Freitas LRS de, Garcia LP. Evolução da prevalência do diabetes e deste associado à hipertensão arterial no Brasil: análise da Pesquisa Nacional por Amostra de Domicílios, 1998, 2003 e 2008. Epidemiol Serv Saúde. 2012;21(1):7-19.

17. Martins MSAS, Ferreira MG, Guimaraes LV, Vianna LAC. Hipertensión arterial y estilo de vida en Sinop, Municipio de la Amazonía Legal. Arq Bras Cardiol.
2010;94(5):621-6.

18. Pontes FLI Junior, Prestes J, Leite RD, Rodriguez D. Influência do treinamento aeróbio nos mecanismos fisiopatológicos da hipertensão arterial sistêmica. Rev Bras Ciênc Esporte. 2010;32(2-4):229-44.

19. Ikeda $N$, Inoue $M$, Isso $H$, Ikeda $S$, Satoh $T$, Noda $\mathrm{M}$, et al. Adult mortality attributable to preventable risk factors for non-communicable diseases and injuries in Japan: a comparative risk assessment. PLoS Med. 2012;9(1):e1001160.

20. Ghosh JR, Bandyopadhyay AR. Comparative evaluation of obesity measures: relationship with blood pressures and hypertension. Singapore Med J. 2007;48(3):232-5.

21. Zhou Z, Hu D, Chen J. Association between obesity indices and blood pressure or hypertension: which index is the best? Public Health Nutrition. 2009; 12(8):1061-71.

22. Feng RN, Zhao C, Wang C, Niu YC, Li K, Guo FC et al. BMI is strongly associated with hypertension, and waist circumference is strongly associated with type 2 diabetes and dyslipidemia, in northern Chinese adults. J Epidemiol. 2012;22(4):317-23.

23. Baigent C, Keech A, Kearney PM, Blackwell L, Buck G, Pollicino $C$, et al. Efficacy and safety of cholesterollowering treatment: prospective meta-analysis of data from 90,056 participants in 14 randomised trials of statins. Lancet. 2005;366:1267-78.

24. Muniz LC, Schneider BC, Silva ICM da, Matijasevich A, Santos IS. Fatores de risco comportamentais acumulados para doenças cardiovasculares no sul do Brasil. Rev. Saúde Pública. 2012;46(3):534-42. 